MORETTI, C.L.; ARAÚJO, A.L.; MATTOS, L.M. Evaluation of different oxygen, carbon dioxide and nitrogen combinations employed to extend the shelf life of fresh-cut collard greens. Horticultura Brasileira, Brasília, v. 21, p. 676-680, outubro-dezembro 2003.

\title{
Evaluation of different oxygen, carbon dioxide and nitrogen combinations employed to extend the shelf life of fresh-cut collard greens
}

\author{
Celso L. Moretti ${ }^{1}$; Alessandra L. Araújo ${ }^{1}$; Leonora M. Mattos ${ }^{2}$ \\ ${ }^{1}$ Embrapa Hortaliças, C. Postal 218, 70359-970 Brasília-DF; 2. Universidade Federal de Lavras, 37200-000 Lavras-MG; E-mail: \\ celso@cnph.embrapa.br
}

\begin{abstract}
Collard greens (Brassica oleracea var. acephala) "Manteiga" were harvested in commercial fields in Brasilia, Brazil, aiming to evaluate different oxygen, carbon dioxide and nitrogen combinations to extend the shelf life of the fresh-cut product. After harvest, leaves were taken to the postharvest laboratory, selected for external blemishes and minimally processed ( $3 \mathrm{~mm}$ thick) inside a cold room $\left(13 \pm 2{ }^{\circ} \mathrm{C}\right)$. After processing, fresh-cut collard greens were stored under two controlled atmosphere $(\mathrm{CA})$ conditions $\left(3 \% \mathrm{O}_{2}, 4 \% \mathrm{CO}_{2}\right.$; $5 \% \mathrm{O}_{2}, 5 \% \mathrm{CO}_{2}$ /balance $\left.\mathrm{N}_{2}\right)$, and normal air (control), at $5^{\circ} \mathrm{C}(95 \pm 2 \%$ $\mathrm{RH})$, for six days. Daily, minimally processed collard greens were evaluated for total vitamin $\mathrm{C}$, total chlorophyll, total soluble solids content, and titratable acidity. Total vitamin $\mathrm{C}$ content decreased for all treatments during the storage period. Storage under CA conditions delayed total vitamin $\mathrm{C}$ degradation for both atmospheres studied. At the end of the storage period, fresh-cut collard greens stored under $3 \% \mathrm{O}_{2}, 4 \% \mathrm{CO}_{2}$ showed around $25 \%$ and $56 \%$ more vitamin $\mathrm{C}$ than the material stored under $5 \% \mathrm{O}_{2}, 5 \% \mathrm{CO}_{2}$ and control, respectively. Total chlorophyll content decreased during the storage period. At the end of the experiment, fresh-cut collard greens stored under 3\% $\mathrm{O}_{2}, 4 \% \mathrm{CO}_{2}$ showed $24 \%$ and $45 \%$ more total chlorophyll than the product stored under $5 \% \mathrm{O}_{2}, 5 \% \mathrm{CO}_{2}$ and control, respectively. CA storage delayed organic acid degradation. On the sixth day, freshcut collard greens stored under $3 \% \mathrm{O}_{2}, 4 \% \mathrm{CO}_{2}$ presented around $44 \%$ more organic acids than control. Total soluble solids content were not significantly affected.
\end{abstract}

Keywords: Brassica oleracea var. acephala, brix, chlorophyll, controlled atmosphere, quality, postharvest, vitamin C.

\section{RESUMO}

Avaliação de diferentes combinações de oxigênio, gás carbônico e nitrogênio utilizadas no aumento de vida de prateleira de couve minimamente processada

Folhas de couve (Brassica oleracea var. acephala) "Manteiga" foram obtidas em campos de produção comercial em Brasília, DF, com o objetivo de avaliar diferentes combinações de oxigênio, dióxido de carbono e nitrogênio para estender a vida de prateleira do produto minimamente processado. Após colhidas, as folhas foram levadas ao laboratório de pós-colheita, selecionadas para danos externos aparentes e minimamente processadas $(3 \mathrm{~mm})$ no interior de uma câmara fria $\left(13 \pm 2^{\circ} \mathrm{C}\right)$. Depois de processado, o material foi armazenado sob duas condições de atmosfera controlada $\left(3 \% \mathrm{O}_{2}\right.$, $4 \% \mathrm{CO}_{2} ; 5 \% \mathrm{O}_{2}, 5 \% \mathrm{CO}_{2}$ /balanço de $\mathrm{N}_{2}$ ), e ar atmosférico (controle), a $5^{\circ} \mathrm{C}(95 \pm 2 \% \mathrm{UR})$, por seis dias. Diariamente, foram avaliados os teores de vitamina $\mathrm{C}$ total, clorofila total, sólidos solúveis totais e acidez titulável. $\mathrm{O}$ teor de vitamina $\mathrm{C}$ total diminuiu para todos os tratamentos durante o período de armazenamento. A degradação da vitamina $\mathrm{C}$ total para as duas atmosferas estudadas foi retardada pelo armazenamento sob atmosfera controlada (AC). Ao final do período de armazenamento, a couve minimamente processada armazenada sob $3 \% \mathrm{O}_{2}, 4 \% \mathrm{CO}_{2}$ apresentava $25 \%$ e $56 \%$ mais vitamina $\mathrm{C}$ total que o material armazenado sob $5 \% \mathrm{O}_{2}, 5 \% \mathrm{CO}_{2}$ e o controle, respectivamente. $\mathrm{O}$ teor de clorofila total diminuiu durante $\mathrm{o}$ período de armazenamento. Ao final do experimento, o material minimamente processado armazenado sob $3 \% \mathrm{O}_{2}, 4 \% \mathrm{CO}_{2}$ apresentava $24 \%$ e $45 \%$ mais clorofila total que o produto armazenado sob $5 \% \mathrm{O}_{2}, 5 \% \mathrm{CO}_{2}$ e controle, respectivamente. O armazenamento sob $\mathrm{AC}$ retardou a degradação de ácidos orgânicos. No sexto dia, a couve minimamente processada armazenada com $3 \% \mathrm{O}_{2}, 4 \% \mathrm{CO}_{2}$ possuía cerca de $44 \%$ mais ácidos orgânicos que o controle. Os teores de sólidos solúveis não foram significativamente afetados.

Palavras-chave: Brassica oleracea var. acephala, atmosfera controlada, brix, clorofila, pós-colheita, qualidade, vitamina $\mathrm{C}$.

\section{(Recebido para publicação em 06 de janeiro de 2003 e aceito em 18 de junho de 2003)}

\begin{abstract}
$\mathrm{A}$ lthough commercialized at higher prices when compared to fresh products, fresh-cut fruits and vegetables have the advantage of being perceived by customers to be fresher than other products, such as frozen or canned food. Since 1994, "fresh" has remained the most desirable food label claim for $79 \%$ of american customers, followed by low fat ( $62 \%)$, and natural
\end{abstract}

$(41 \%)$. Besides that, freshness is a serious issue for shoppers and retailers, being the third reason for selecting a primary supermarket, just behind high quality and a "clean and neat store" (Sloan, 2000). In Brazil, the fresh-cut industry started at the beginning of the 1980 's and is increasing considerably every year. This increase is partly due to the enormous growth of the food- service segment ( $150 \%$ during the last 7 years) (Moretti \& Sargent, 2002).

Fresh-cut products represent around $10 \%$ of the American fresh fruit and vegetable market, resulting in a volume of 8 to 10 billion dollars per year (Cantwell, 2000). The consumption of fresh-cut products is increasing year after year, showing many advantages when compared to fresh products. 
While most food technologies available are designed to extend the shelf life of perishable products, minimal processing abbreviates the conservation of fruits and vegetables. This is basically due to the mechanical injuries occurred during the different steps involved in the obtention of a fresh-cut product. Thus, changes in carbon dioxide evolution (Moretti et al., 2000) and increase in the activity of many enzymes related to browning (Bower \& Van Lelyveld, 1985; Ke \& Saltveit, 1989; King \& Bolin, 1989; Nicoli et al., 1994; Brecht, 1995; Moretti et al., 2002) are events that are commonly associated with fresh-cut tissues.

The best way to circumvent the alterations caused by mechanical damages is a strict temperature control. Respiration and deterioration rates can be rapidly decreased by storage under refrigerated conditions (Moretti, 2001). Another important tool to control respiration rates and deterioration is modified atmosphere (MA). Unfortunately, limited information is available regarding respiration rates of fresh-cut products under controlled or modified atmosphere conditions. Matilla et al. (1995) verified that storage under modified atmosphere $\left(5 \% \mathrm{O}_{2}, 5 \%\right.$ $\mathrm{CO}_{2}$ ) only slightly reduced the respiration rates of fresh-cut carrots, leek and onion, but increased slightly the rates of fresh-cut potatoes. The increase in oxygen demand caused by the increased respiratory activity dictates plastic film permeability, in order to avoid anaerobic conditions (Cantwell, 2000).

Working on fresh-cut strawberries, peaches and honeydew, Watada et al. (1996) observed that controlled atmospheres of $1-2 \% \mathrm{O}_{2}+10 \% \mathrm{CO}_{2}$ reduced respiration rates by 25 to $50 \%$ at $5^{\circ} \mathrm{C}$. These same atmospheres also substantially reduced ethylene production rates and softening of fruit tissues. MA also had a positive effect in retarding microbial growth, softening, color change, and offodors in fresh-cut cantaloupe stored under high $\mathrm{CO}_{2}$ atmospheres in air or low $\mathrm{O}_{2}$ (Cantwell, 2000).

Despite all the interest and work done with minimally processed products, processors still face many technological problems. Minimal processing of collard greens has shown to be a great challenge for processors basically due to its high respiratory activity after processing. One of the strategies carried out to reduce respiration rates and to extend the shelf life is the utilization of modified atmosphere packaging in conjunction with low temperatures. Different plastic films have already been tested and the shelf life achieved is only around 6 days. Teles (2001) verified that the utilization of plastic films (multi-layer nylon) in association with active atmosphere modification can be a way to extend fresh-cut collard greens shelf life. However, different oxygen, carbon dioxide and nitrogen combinations still need to be evaluated.

The present work was carried out aiming to evaluate different oxygen, carbon dioxide and nitrogen combinations to extend the shelf life of fresh-cut collard greens.

\section{MATERIAL AND METHODS}

\section{Plant material}

Collard greens (Brassica oleracea var. acephala) leaves "Manteiga" were harvested in commercial fields in Brasilia. After harvest, leaves were taken to the postharvest laboratory in plastic containers topped with crushed ice, selected for external blemishes and minimally processed ( $3 \mathrm{~mm}$ thick) inside a cold room $\left(13 \pm 2^{\circ} \mathrm{C}\right)$. After processing, fresh-cut collard greens were stored for 6 days under two controlled atmosphere (CA) conditions $\left(3 \% \mathrm{O}_{2}, 4 \% \mathrm{CO}_{2} ; 5 \% \mathrm{O}_{2}, 5 \% \mathrm{CO}_{2} /\right.$ balance $\mathrm{N}_{2}$ ), and normal air (control), at $5 \pm 1^{\circ} \mathrm{C}$ and $95 \pm 2 \% \mathrm{RH}$, and evaluated daily.

\section{Chemical and physical analysis}

Fresh-cut collard greens were evaluated for total vitamin $\mathrm{C}$, total chlorophyll, total soluble solids content, and titratable acidity.

\section{Total vitamin $\mathbf{C}$}

For total vitamin $\mathrm{C}$ analysis, $2 \mathrm{~g}$ of homogenized tissue were combined with $20 \mathrm{~mL}$ of $6 \%$ metaphosphoric acid in $2 \mathrm{~N}$ acetic acid and centrifuged for
$20 \mathrm{~min}$ at $18,000 \mathrm{~g}$ at $4^{\circ} \mathrm{C}$. The analysis was performed by the dinitrophenylhydrazine method of Terada et al. (1978). The concentration of total vitamin $\mathrm{C}$ was calculated in $\mathrm{mg}$ $\mathrm{kg}^{-1}$ of fresh weight from absorbance measured at $540 \mathrm{~nm}$ using pure ascorbic acid as a standard.

\section{Total chlorophyll}

Total chlorophyll was determined according to Inskeep \& Bloom (1985). Two $g$ of tissue were added to aluminum foil-covered vials containing $5 \mathrm{~mL}$ of $\mathrm{N}, \mathrm{N}$ dimethylformamide (DMF). After 10 days at $4^{\circ} \mathrm{C}$, solutions were filtered through Miracloth and absorbance read at $647 \mathrm{~nm}$ and $664.5 \mathrm{~nm}$. Pigments were expressed as $\mathrm{mg} \mathrm{kg}^{-1}$ of fresh tissue.

Titratable acidity and soluble solids

Determination of titratable acidity and soluble solids content was performed according to Moretti et al. (1998). Forty grams of the fresh tissue were homogenized in a commercial blender at high speed and centrifuged for $15 \mathrm{~min}$ at $18,000 \mathrm{~g}$. Aliquots of the supernatant were diluted with $50 \mathrm{~mL}$ of deionized water and titrated with $0.1 \mathrm{~N}$ $\mathrm{NaOH}$ to an end point of $\mathrm{pH} 8.2$ using an automatic titrimeter. The amount of $\mathrm{NaOH}$ was converted to miliequivalents of citric acid per kg of fresh weight ( $\mathrm{mL}$ $\mathrm{NaOH} \times 0.1 \mathrm{~N}$ x 0.064). Soluble solids content was determined using a benchtop digital refractometer.

\section{Experimental design and statistical analysis}

Analysis were performed using a completely randomized design, with 21 treatments arranged in a factorial scheme (two controlled atmosphere conditions: $3 \% \mathrm{O}_{2}, 4 \% \mathrm{CO}_{2} ; 5 \% \mathrm{O}_{2}, 5 \% \mathrm{CO}_{2} /$ balance $\mathrm{N}_{2}$ ), and normal air (control), 7 sampling times, and 3 replicates. Data were subjected to analysis of variance and the least significant difference procedure was carried out. Differences between any two treatments larger than the sum of two standard deviations were always significant $(\mathrm{P}=0.05)$.

\section{RESULTS AND DISCUSSION}

\section{Total vitamin $\mathbf{C}$}

Total vitamin $\mathrm{C}$ content decreased for all treatments during the storage 


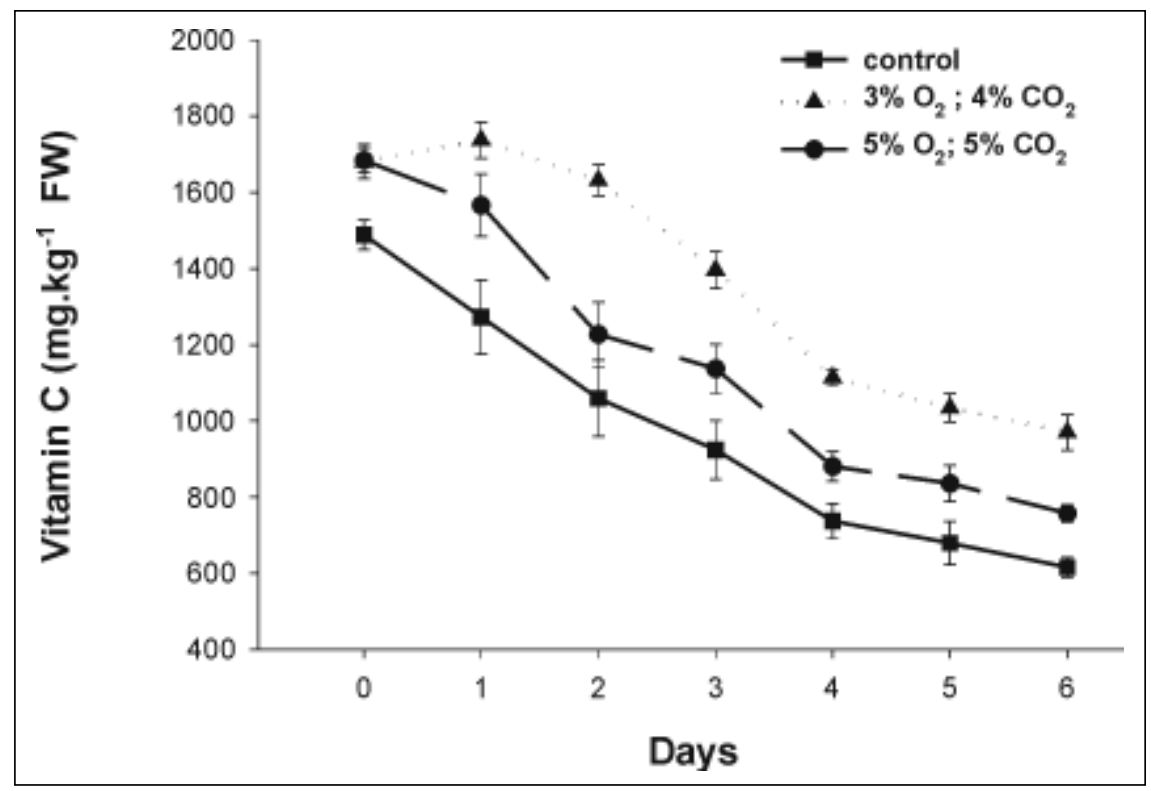

Figure 1. Total vitamin $\mathrm{C}$ content $\left(\mathrm{mg}^{\mathrm{kg}} \mathrm{kg}^{-1} \mathrm{FW}\right)$ of fresh-cut collard greens stored under controlled atmosphere $\left(3 \% \mathrm{O}_{2} ; 4 \% \mathrm{CO}_{2}\right.$; balance $\mathrm{N}_{2}$ and $5 \% \mathrm{O}_{2} ; 4 \% \mathrm{CO}_{2}$; balance $\left.\mathrm{N}_{2}\right)$ and control $\left(78 \% \mathrm{~N}_{2} ; 21 \% \mathrm{O}_{2}\right)$, at $5^{\circ} \mathrm{C}$ for 6 days. Vertical bars indicate \pm SD. Brasília, Embrapa Hortaliças, 2002.

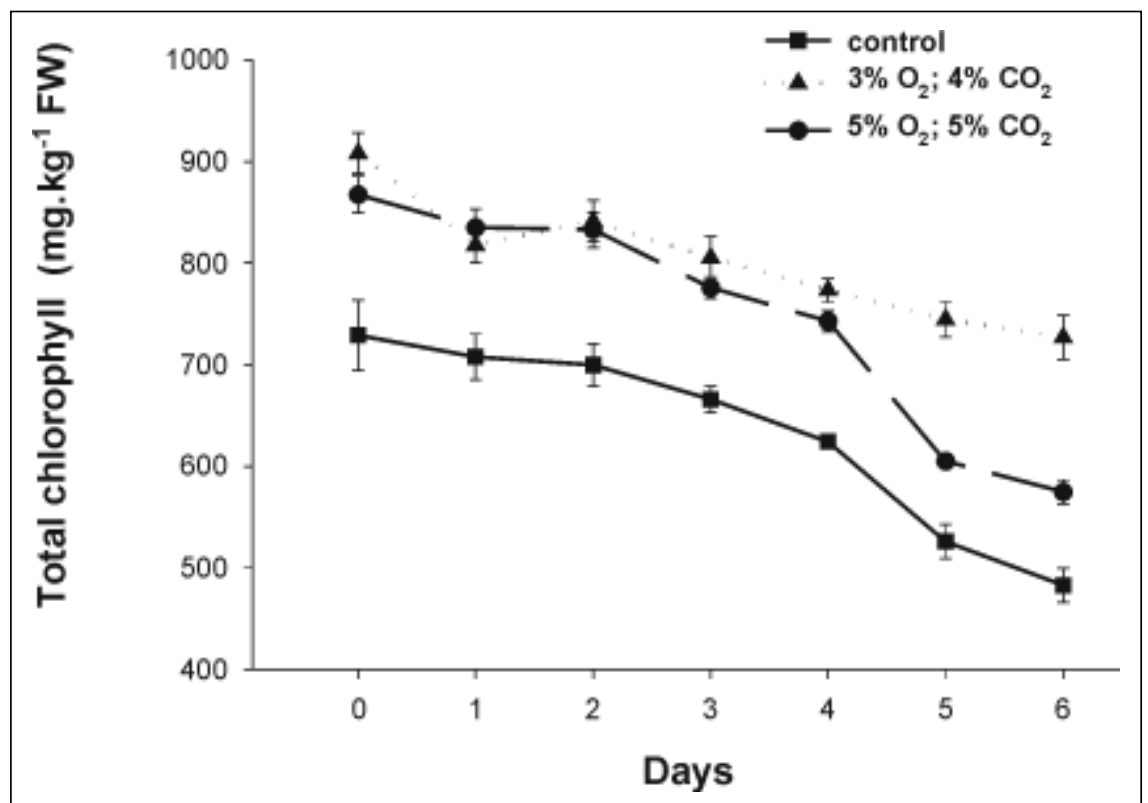

Figure 2. Total chlorophyll content $\left(\mathrm{mg} . \mathrm{kg}^{-1} \mathrm{FW}\right)$ of fresh-cut collard greens stored under controlled atmosphere $\left(3 \% \mathrm{O}_{2} ; 4 \% \mathrm{CO}_{2}\right.$; balance $\mathrm{N}_{2}$ and $5 \% \mathrm{O}_{2} ; 4 \% \mathrm{CO}_{2}$; balance $\left.\mathrm{N}_{2}\right)$ and control $\left(78 \% \mathrm{~N}_{2} ; 21 \% \mathrm{O}_{2}\right)$, at $5^{\circ} \mathrm{C}$ for 6 days. Vertical bars indicate \pm SD. Brasília, Embrapa Hortaliças, 2002.

period. Storage under CA conditions delayed total vitamin $\mathrm{C}$ degradation for both atmospheres studied. At the end of the storage period, fresh-cut collard greens stored under $3 \% \mathrm{O}_{2}, 4 \% \mathrm{CO}_{2}$ showed around $25 \%$ and $56 \%$ more vitamin $\mathrm{C}$ than the same material stored under $5 \% \mathrm{O}_{2}, 5 \%$ $\mathrm{CO}_{2}$ and control, respectively (Figure 1).

Senesi et al. (2000) studied the effect of modified atmosphere packaging on color, firmness, vitamin $\mathrm{C}$ (ascorbic acid), microbial quality and sensory characteristics of fresh-cut green bell peppers stored at $8 \pm 1^{\circ} \mathrm{C}$ for up to 11 days. Vitamin $\mathrm{C}$ content and the organoleptic characteristics were acceptable at the end of the storage period.

The effect of modified atmosphere packaging (MAP) on vitamin $\mathrm{C}$ content (ascorbic + dehydroascorbic acid; AA + DHAA) of fresh-cut spinach was evaluated by Gil et al. (1999). They verified that vitamin $\mathrm{C}$ was better preserved in MAP-stored spinach when compared to normal air.

Watada (1987) observed that vitamin $\mathrm{C}$ degradation is product, temperature and atmosphere dependent. He also verified that reduction in oxygen concentration in the storage ambient delayed ascorbic acid degradation. However, different species responded differently to distinct atmospheres combinations.

\section{Total chlorophyll}

Total chlorophyll content decreased during the storage period (Figure 2). After the fourth day, chlorophyll degradation occurred slowly for freshcut collard greens stored under $3 \% \mathrm{O}_{2}$, $4 \% \mathrm{CO}_{2}$ when compared to other treatments, which was a clear sign that controlled atmosphere storage was an efficient method to delay pigment degradation. At the end of the experiment, fresh-cut collard greens stored under $3 \% \mathrm{O}_{2}, 4 \% \mathrm{CO}_{2}$ showed $24 \%$ and $45 \%$ more total chlorophyll than the product stored under $5 \% \mathrm{O}_{2}, 5 \%$ $\mathrm{CO}_{2}$ and control, respectively (Figure 2). Considering the retention of the initial total chlorophyll content, it was observed that storage under $3 \% \mathrm{O}_{2}, 4 \%$ $\mathrm{CO}_{2}$ allowed a retention of around $80 \%$ of the initial content (Figure 2).

The effects of modified atmosphere packaging and controlled atmosphere storage on the storability of snow pea pods (Pisum sativum var. saccharatum) at $5^{\circ} \mathrm{C}$ were determined by Pariasca et al. (2001). Bagging pods with polymethyl pentene polymeric films modified the in-bag atmosphere concentration to approximately $5 \mathrm{kPaO}_{2}$ and $5 \mathrm{kPa} \mathrm{CO}_{2}$, leading to better maintenance of the pod internal quality (chlorophyll, ascorbic acid, and sugar contents).

\section{Titratable acidity}

Controlled atmosphere storage delayed organic acid degradation. Freshcut collard greens stored under $3 \% \mathrm{O}_{2}$, $4 \% \mathrm{CO}_{2}$ showed the highest titratable acidity at the end of the storage period, having around 8 and $18 \%$ more organic 
acids than the treatment stored under $5 \%$ $\mathrm{O}_{2}, 5 \% \mathrm{CO}_{2}$ and control, respectively (Figure 3). Lau \& Looney (1982) also verified that storage under controlled atmosphere delayed organic acid degradation in intact apples. Gonzalez et al. (2000) studied the combination of antibrowning agents and modified atmosphere packaging to extend the shelf life of fresh-cut mangoes stored at $10^{\circ} \mathrm{C}$. Combinations of several browning inhibitors were more effective than those applied individually and did not affect significantly the changes in organic acids and sugar content of slices during 14 days of storage at $10^{\circ} \mathrm{C}$.

\section{Total soluble solids}

Total soluble solids content were not significantly affected. It was verified that fresh-cut collard greens stored under 3\% $\mathrm{O}_{2}, 4 \% \mathrm{CO}_{2}$ had a higher content of total soluble solids, despite the difference not being statistically significant. On the other hand, it was verified that the fresh-cut product stored under normal atmosphere showed the lowest content of total soluble solids during the storage period, being $6 \%$ lower than the treatment stored under 3\% $\mathrm{O}_{2}, 4 \% \mathrm{CO}_{2}$ at the sixth day (Figure 4).

Teixeira et al. (2001) studied the effect of cutting size, storage temperature, atmosphere modification rate and chemical characteristics of 'Formosa' fresh-cut papaya packed in plastic cups $(500 \mathrm{ml})$. They verified that total soluble solids content did not vary among treatments.

Considering the conditions under wich this work was carried out, it is recommended that fresh-cut collard greens shall be stored under $3 \% \mathrm{O}_{2}, 4 \%$ $\mathrm{CO}_{2}$ (balance $\mathrm{N}_{2}$ ) and $5^{\circ} \mathrm{C}$ to maintain the quality and extend the shelf life of the processed product.

\section{LITERATURE CITED}

BOWER, J.P.; VAN LELYVELD, L.J. The effects of stress history and container ventilation on avocado fruits polyphenol oxidase activity Journal of Horticultural Science, v. 60, p. 545547, 1985.

BRECHT, J.K. Physiology of lightly processed fruits and vegetables. Hortscience, v. 30, n. 1, p. 18-24, 1995.

CANTWELL, M.I. Preparation and quality of fresh-cut produce. In: ENCONTRO NACIONAL SOBRE PROCESSAMENTO MÍNIMO DE FRUTAS E HORTALIÇAS, 2., 2000, Viçosa. Anais... Viçosa: UFV, 2000. p. 156-182.

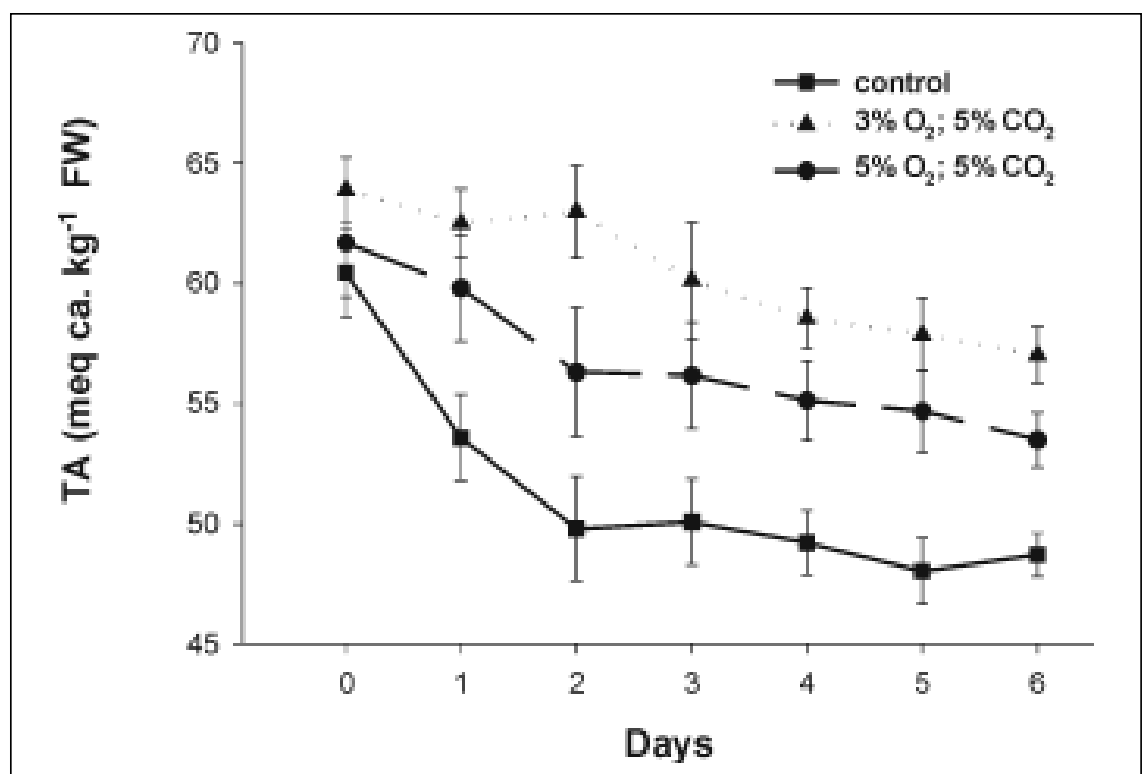

Figure 3. Titratable acidity (meq ca.kg-1 $\mathrm{FW}$ ) of fresh-cut collard greens stored under controlled atmosphere $\left(3 \% \mathrm{O}_{2} ; 4 \% \mathrm{CO}_{2}\right.$; balance $\mathrm{N}_{2}$ and $5 \% \mathrm{O}_{2} ; 4 \% \mathrm{CO}_{2}$; balance $\left.\mathrm{N}_{2}\right)$ and control $\left(78 \% \mathrm{~N}_{2} ; 21 \% \mathrm{O}_{2}\right)$, at $5^{\circ} \mathrm{C}$ for 6 days. Vertical bars indicate \pm SD. Brasília, Embrapa Hortaliças, 2002.

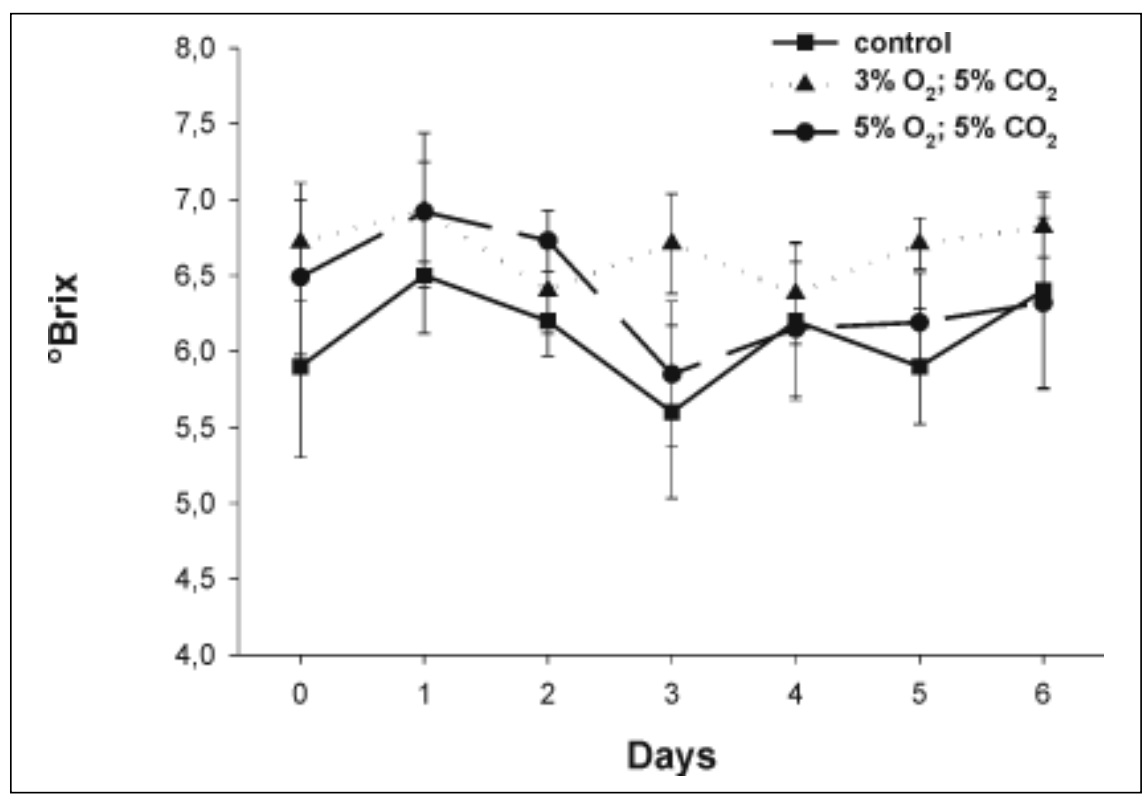

Figure 4. Total soluble solids ( ${ }^{\circ} \mathrm{Brix}$ ) of fresh-cut collard greens stored under controlled atmosphere $\left(3 \% \mathrm{O}_{2} ; 4 \% \mathrm{CO}_{2} ;\right.$ balance $\mathrm{N}_{2}$ and $5 \% \mathrm{O}_{2} ; 4 \% \mathrm{CO}_{2}$; balance $\left.\mathrm{N}_{2}\right)$, and control $\left(78 \% \mathrm{~N}_{2} ; 21 \% \mathrm{O}_{2}\right)$, at $5^{\circ} \mathrm{C}$ for 6 days. Vertical bars indicate \pm SD. Brasília, Embrapa Hortaliças, 2002.

GIL, M.I.; FERRERES, F.; TOMASBARBERAN, F.A. Effect of postharvest storage and processing on the antioxidant constituents (flavonoids and vitamin C) of fresh-cut spinach. Journal of Agricultural and Food Chemistry, v. 47, n. 6, p. 2213-2217, 1999.

GONZALEZ-AGUILAR, G.A.; WANG, C.Y.; BUTA, J.G. Maintaining quality of fresh-cut mangoes using antibrowning agents and modified atmosphere packaging. Journal of Agricultural and Food Chemistry, v. 48, n. 9, p. 4204-4208, 2000 .
INSKEEP, W.P.; BLOOM, P.R. Extinction coefficients of chlorophyll $a$ and $b$ in N,NDimethylformamide and $80 \%$ acetone. Plant Physiology, v. 77, p.483-485, 1985.

KE, D.; SALTVEIT, M.E. Wound induced ethylene production, phenolic metabolism, and susceptibility to russet spotting in iceberg lettuce. Plant Physiology, v. 76, p. 412-418, 1989.

KING, A.D.; BOLIN, H.R. Physiological and microbiological storage stabilty of minimally processed fruits and vegetables. Food Technology, v. 43, p. $132-139,1989$ 
LAU, O.L.; LOONEY, N.E. Improvement of fruit firmness and acidity in controlled-atmospheresstored "Golden Delicious" apples by a rapid $\mathrm{O}_{2}$ reduction procedure. Journal of the American Society for Horticultural Science, v. 107, p. 531535, 1982.

MATTILA, M.; AHVENAINEN, R.; HURME, E.; HYVONEN, L. Respiration rates of some minimally processed vegetables. In: WORKSHOP POSTHARVEST TREATMENT OF FRUITS AND VEGETABLES. Proceedings... Viena: Commission European Communities, 1995. p. 135-145.

MORETTI, C.L.; SARGENT, S.A.; HUBER, D.J.; CALBO, A.G.; PUSCHMANN, R. Chemical composition and physical properties of pericarp, locule and placental tissues of tomatoes with internal bruising. Journal of the American Society for Horticultural Science, v. 123, n. 4, p. 656660, 1998.

MORETTI, C.L.; SILVA, W.L.C., ARAUJO, A.L. Quality attributes and carbon dioxide evolution of bell peppers as affected by minimal processing and storage temperature. Proceedings of the Florida State Horticultural Society, v. 113, p. 156159, 2000.

MORETTI, C.L. Technology of fresh-cut products. In: BRAZILIAN CONGRESS OF AGRICULTURAL ENGINEERING, 3., 2001, Foz do Iguaçu. Proceedings... Foz do Iguaçu: SBEA, 2001. p. 357-364.
MORETTI, C.L.; ARAUJO, A.L.; MAROUELLI, W.A.; SILVA, W.L.C. Respiratory activity and browning of minimally processed sweet potatoes. Horticultura Brasileira, Brasília, v. 20, n. 3, p. 497-500, 2002.

MORETTI, C.L.; SARGENT, S.A. Fresh-cut growth in Brazil. Fresh-cut Magazine, v. 10, p. 24-29, 2002.

NICOLI, M.C.; ANESE, M.; SEVERINI, C. Combined effects in preventing enzymatic browning reactions in minimally processed fruit. Journal of Food Quality, v. 17, p. 221-229, 1994. PARIASCA, J.A.T.; MIYAZAKI, T.; HISAKA, H.; NAKAGAWA, H.; SATO, T. Effect of modified atmosphere packaging (MAP) and controlled atmosphere (CA) storage on the quality of snow pea pods (Pisum sativum L. var. saccharatum). Postharvest Biology and Technology, v. 21, n. 2, p. 213-223, 2001.

SENESI, E; PRINZIVALLI, C; SALA, M; GENNARI, M. Physicochemical and microbiological changes in fresh-cut green bell peppers as affected by packaging and storage. Italian Journal of Food Science, v. 12, n. 1, p. 55 64, 2000.

SLOAN, E.A. A taste of tomorrow. In: UC Davis, Postharvest Technology. Fresh-cut products: maintaining quality and safety. Davis: University of California: Postharvest Technology and Information Center, 2000. 23 p.
TEIXEIRA, G.H.A.; DURIGAN, J.F.; MATTIUZ, B.H.; ROSSI-JUNIOR, O.D. Fresh-cut of 'Formosa' papaya. Ciência e Tecnologia de Alimentos, Campinas, v. 21, n. 1, p. 47-50, 2001.

TELES, C.S. Utilization of modified atmosphere storage to extend the shelf life of minimally processed collard greens (Brassica oleraceae, L. var. acephala), 2001. Federal University of Viçosa, Viçosa, MG, Brazil, 115 p. (MSc. Dissertation). (In Portuguese).

TERADA, M.; WATANABE, Y.; KUNITOMA, M.; HAYASHI, E. Differential rapid analysis of ascorbic acid and ascorbic acid 2-sulfate by dinitrophenilhydrazine method. Annals of Biochemistry, v. 84, p. 604-608, 1978.

WATADA, A.E. Vitamins. In: Weichmman, J. (Ed.). Postharvest physiology of vegetables. New York: Marcel Dekker Inc., 1987. p. 455-468.

WATADA, A.E.; KO, N.P.; MINOTT, D.A. Factors affecting quality of fresh-cut horticultural products. Postharvest Biology and Technology, v. 9, p. 115-125, 1996. 